\title{
Efeito da Ropivacaína na Recaptação Neuronal de Noradrenalina em Músculo Liso *
}

\section{Effect of Ropivacaine on Neuronal Norepinephrine Reuptake in Smooth Muscle}

Carlos Alberto de Souza Martins, TSA ${ }^{1}$; Pedro Wanderley de Aragão ${ }^{2}$; Sonia Maria de Farias Freire ${ }^{3}$; Mahiba Mattar Rahbani de Souza Martins s ; Marilene Oliveira da Rocha Borges ${ }^{5}$; Antonio Carlos Romão Borges ${ }^{6}$

\begin{abstract}
RESUMO
Martins CAS, Aragão PW, Freire SMF, Martins MMRS, Borges MOR, Borges ACR - Efeito da Ropivacaína na Recaptação Neuronal de Noradrenalina em Músculo Liso
\end{abstract}

JUSTIFICATIVA E OBJETIVOS: Além da ação anestésica local, a ropivacaína apresenta efeito vasoconstritor clinicamente significativo, que pode ser observado quando da anestesia infiltrativa, o que a torna um anestésico importante no bloqueio de campo. Este trabalho teve por objetivo caracterizar o mecanismo de ação constritora da ropivacaína em músculo liso.

MÉTODO: Em preparações isoladas de ducto deferente de ratos foram construídas curvas concentração-efeito de noradrenalina na ausência ou na presença da ropivacaína. Em outra série de experimentos os ratos foram tratados com reserpina (10 mg. $\mathrm{kg}^{-1}$, por via intraperitoneal) para avaliar a reatividade dos ductos deferentes à tiramina ou noradrenalina, na ausência ou presença da ropivacaína.

RESULTADOS: A ropivacaína nas concentrações de 5 ou 10 $\mu \mathrm{g} \cdot \mathrm{mL}^{-1}$ potencializou o efeito máximo (Emax) da noradrenalina em $47 \%$ e $35 \%$, respectivamente, enquanto que nas concentrações de 50 ou $100 \mu \mathrm{g} \cdot \mathrm{mL}^{-1}$ inibiu o efeito máximo produzido por este agonista. Em ductos deferentes isolados de ratos reserpinizados, a ropivacaína (10 ou $20 \mu \mathrm{g} \cdot \mathrm{mL}^{-1}$ )

* Recebido do (Received from) Laboratório de Farmacologia do Departamento de Ciências Fisiológicas da Universidade Federal do MaranhãoUFMA. São Luís, MA

1. Responsável pelo Serviço de Anestesiologia da Clínica São Marcos; Professor Adjunto da Disciplina de Farmacologia da UFMA. Mestre em Ciências da Saúde pela UFMA

2. Professor Adjunto da Disciplina de Farmacologia da UFMA; Coordenador do Centro de Estudos da Clínica São Marcos: Mestre em Ciências da Saúde pela UFMA

3. Professora Adjunta da Disciplina de Farmacologia e Diretora do Biotério Central da UFMA; Mestre em Farmacologia pela Universidade Federal de São Paulo - UNIFESP

4. Professora Adjunta da Disciplina de Farmacologia da UFMA; Mestre em Ciências da Saúde pela UFMA

5. Professora Adjunta da Disciplina de Farmacologia e Coordenadora do cologia pela UNIFESP

6. Professor Adjunto da Disciplina de Farmacologia da UFMA; Coordenador do Programa de Monitoração de Propaganda e Publicidade de Produtos sob Vigilância Sanitária no Maranhão

Apresentado (Submitted) em 26 de janeiro de 2005

Aceito (Accepted) para publicação em 10 de junho de 2005

Endereço para correspondência (Correspondence to)

Dr. Carlos Alberto de Souza Martins

Avenida Grande Oriente, Quadra $47 n^{\circ} 23$

65075-180 São Luís, MA

E-mail:desmartins@zipmail.com.br-pedro.aragao@elo.com.br

(C) Sociedade Brasileira de Anestesiologia, 2005 Curso de Mestrado em Ciências da Saúde da UFMA; Doutora em Farma-

potencializou (150\% e 25\%, respectivamente) as contrações induzidas pela noradrenalina, enquanto que as concentrações de 50 ou $100 \mu \mathrm{g} \cdot \mathrm{mL}^{-1}$ não alteraram as respostas à noradrenalina.

CONCLUSÕES: Os resultados obtidos permitem concluir que a ropivacaína bloqueia a recaptação neuronal de noradrenalina pelos terminais nervosos simpáticos.

Unitermos: ANESTESIA, Experimental; ANESTÉSICOS, Local: ropivacaína; SISTEMA NERVOSO AUTONNOMO, Simpático

\section{SUMMARY}

Martins CAS, Aragão PW, Freire SMF, Martins MMRS, Borges MOR, Borges ACR - Effect of Ropivacaine on Neuronal Norepinephrine Reuptake in Smooth Muscle

BACKGROUND AND OBJECTIVES: In addition to local anesthetic action, ropivacaine has clinically significant vasoconstrictor effects, which may be observed at infiltrative anesthesia, making it an important anesthetic for field blockade. This study aimed at characterizing the constrictor mechanism of ropivacaine on smooth muscles.

METHODS: Norepinephrine concentration-effect curves in the absence or presence of ropivacaine were plotted on isolated preparations of vas deferens of rats. In another series of experiments rats were treated with reserpine $\left(10 \mathrm{mg}^{\mathrm{kg}}{ }^{-1}\right.$, i.p. $)$ to evaluate vas deferens reactivity to tyramine or norepinephrine, in the absence or presence of ropivacaine.

RESULTS: Ropivacaine 5 or $10 \mu \mathrm{g} \cdot \mathrm{mL}^{-1}$ potentiated maximum norepinephrine effect (Emax) in $47 \%$ and $35 \%$, respectively, while higher concentrations (50 or $100 \mu \mathrm{g} \cdot \mathrm{mL}^{-1}$ ) inhibited its maximum effect. In isolated vas deferens of rats treated with reserpine, ropivacaine $\left(10\right.$ or $\left.20 \mu \mathrm{g} \cdot \mathrm{mL}^{-1}\right)$ potentiated $(150 \%$ and $25 \%$, respectively) norepinephrine-induced contractions, while higher concentrations (50 or $100 \mu \mathrm{g} \cdot \mathrm{mL}^{-1}$ ) have not changed responses to norepinephrine.

CONCLUSIONS: Ropivacaine blocks neuronal norepinephrine reuptake by sympathetic nerve terminals.

Key Words: ANESTHESIA, Experimental; ANESTHETICS, Local: ropivacaine; AUTONOMOUS NERVOUS SYSTEM, Simpatico

\section{INTRODUÇÃO}

Aropivacaína (cloridrato de 1-propil-2`,6-pipecoloxylidiAda) é um anestésico local de longa duração, quimicamente homóloga à mepivacaína e à bupivacaína. Estudos pré-clínicos demonstraram que a ropivacaína apresenta menos toxicidade para os sistemas nervoso central e cardiovascular em comparação à bupivacaína ${ }^{1}$, que é a droga mais usada em bloqueios anestésicos, em função de seu tempo prolongado de ação. Em estudos clínicos, voluntá- 
rios sadios, submetidos à infusão venosa de ropivacaína, mostraram alterações menos intensas relativas a esses dois sistemas ${ }^{2,3}$, o que é sobremaneira interessante haja vista a possibilidade sempre presente de uma concentração elevada chegar ao sangue como conseqüência de uma injeção intravascular inadvertida. Embora este anestésico apresente propriedades bloqueadoras de nervos sensoriais, similares às observadas com a bupivacaína ${ }^{4}$, o mesmo não acontece em relação ao bloqueio motor, pois há uma bem demonstrada separação sensório-motora com a ropivacaína ${ }^{5,6}$. Outra propriedade da ropivacaína é a sua ação vasoconstritora clinicamente significativa ${ }^{7}$, observada durante a anestesia infiltrativa, o que a torna um anestésico importante no bloqueio de campo ${ }^{8}$. A adição de adrenalina a este anestésico, portanto, não é um fator importante para a redução da absorção a partir do local da injeção ou para o prolongamento de seu efeito ${ }^{9}$, como ocorre com os demais anestésicos locais, à exceção da cocaína. Estudos pré-clínicos demonstraram que a injeção de altas concentrações de ropivacaína promove vasoconstrição na medula espinhal de ratos, reversível após 20 minutos ${ }^{10}$. Esta ação vasoconstritora da ropivacaína e da cocaína, não é compartilhada por outros anestésicos locais como a bupivacaína, embora haja semelhança química entre ambas. Ao contrário, a bupivacaína causa relaxamento vascular após contração por estímulo químico ou elétrico. Este efeito relaxante é devido à depressão da neurotransmissão adrenérgica, além da inibição da atividade do músculo liso vascular ${ }^{11}$. Considerando que o efeito anestésico local é decorrente da ação do anestésico nos canais de sódio e que estes exercem pouca influência na contração do músculo liso vascular, é viável supor que a vasoconstrição induzida por ropivacaína seja em decorrência de interferência com o sistema nervoso autônomo simpático, à semelhança da cocaína, alcalóide obtido da planta eritroxylon coca, caracterizada por apresentar ação anestésica local e bloqueadora da recaptação neuronal de noradrenalina ${ }^{12}$. Este trabalho, portanto, teve por objetivo caracterizar o mecanismo da ação constritora da ropivacaína em músculo liso.

\section{MÉTODO}

Para realização deste estudo foram utilizados ratos Wistar da espécie Rattus norvegicus, (200-220 g, com 60 dias), variedade albino, e oriundos do Biotério da Universidade Federal do Maranhão. Os animais foram adaptados ao laboratório de farmacologia por 15 dias, antes do início do experimento e mantidos em ambiente controlado. Os animais receberam água e ração ad libitum, durante o período do estudo. Todos os procedimentos e protocolos deste estudo foram submetidos e aprovados pelo Comitê de Ética para Pesquisa do Hospital Universitário Presidente Dutra, UFMA.

Os ratos foram anestesiados com éter sulfúrico e sacrificados por secção dos vasos cervicais. Os ductos deferentes foram dissecados e a sua luz lavada com líquido nutritivo de vesícula (LNV) com a seguinte composição em $\mathrm{mM}: \mathrm{NaCl}=$ 138; $\mathrm{KCl}=5,7 ; \mathrm{NaH}_{2} \mathrm{PO}_{4}=0,4 ; \mathrm{NaHCO}_{3}=15 ;$ Glicose = 5,5;
$\mathrm{CaCl}_{2}=1$,8. Em seguida as preparações foram montadas em câmara para contração de órgão isolado, contendo LNV aerado, a $30^{\circ} \mathrm{C}$ e adaptadas a um sistema de registro sob tensão de $1 \mathrm{~g}$. Após estabilização do sistema (30 min) curvas concentração-efeito de noradrenalina foram obtidas na ausência ou na presença da ropivacaína ou cocaína. Curvas concentração-efeito foram, também, obtidas em ratos tratados com reserpina por via intraperitoneal ${ }^{13}\left(10 \mathrm{mg} \cdot \mathrm{kg}^{-1}\right)$ e sacrificados após 24 horas, para avaliação da reatividade dos ductos à tiramina e noradrenalina na ausência ou na presença da ropivacaína. As percentagens das contrações em função da máxima produzida pela noradrenalina, nas curvas controles, foram relacionadas aos logaritmos negativos das concentrações molares do agonista. Das curvas concentração-efeito obtidas foram determinadas a $\mathrm{EC}_{50}$ (concentração efetiva $50 \%$ ), o pD 2 (logaritmo negativo da $E_{50}$ ) e o $E_{\max }$ (efeito máximo) produzido pela noradrenalina na ausência e na presença de ropivacaína ou cocaína ${ }^{14}$. Os valores de $\mathrm{pD}_{2}$ e $E_{\max }$ foram expressos como média \pm erro padrão das médias (S.E.M.) e as diferenças entre os efeitos de noradrenalina, na ausência e na presença de ropivacaína ou cocaína, foram determinadas pelo teste $t$ de Student para um nível de significância de $5 \%(p<0,05)^{15}$.

\section{RESULTADOS}

A adição sucessiva de noradrenalina produziu contrações dependentes de concentração, atingindo o $E_{\max } \operatorname{com} 0,1 \mathrm{mM}$ e produzindo um valor de $\mathrm{pD}_{2}=5,2 \pm 0,03$. A incubação de ropivacaína $\left(5,25,50\right.$ ou $\left.100 \mu \mathrm{g} \cdot \mathrm{mL}^{-1}, 10 \mathrm{~min}\right)$ produziu contração de baixa amplitude e não dependente de concentração. Além disso, não alterou de forma significativa a sensibilidade $\left(\mathrm{pD}_{2}\right)$ do sistema $\alpha_{1}$-adrenoceptor para noradrenalina em ducto deferente de rato (Figura 1 e Tabela I).

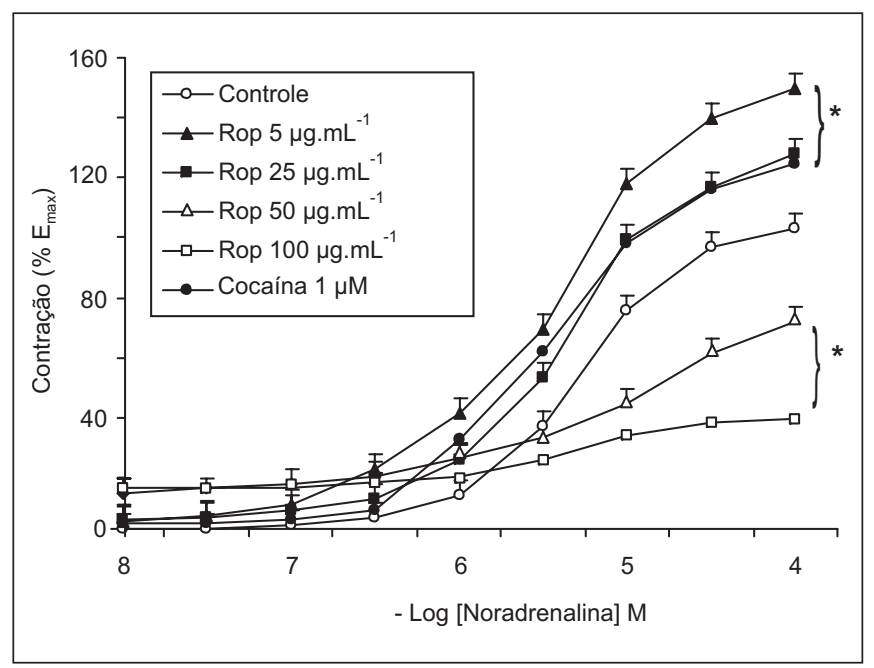

Figura 1 - Efeito da Ropivacaína ou Cocaína na Contração Induzida pela Noradrenalina (controle) em Ductos Deferentes Isolados de Ratos não Reserpinizados

Os símbolos e barras verticais representam, respectivamente, a média \pm S.E.M, $n=5$

${ }^{*} p<0,05$ versus noradrenalina na ausência de ropivacaína (controle) 
Tabela I - Valores de $\mathrm{pD}_{2}$ e Variação de $\mathrm{E}_{\max }$ Obtidos das Curvas Concentração-Respostas de Noradrenalina na Ausência e Presença de Ropivacaína ou Cocaína

\begin{tabular}{lcc}
\hline Grupos & $\mathrm{pD}_{2}$ & $\begin{array}{c}\text { Variação de Emax } \\
(\%)\end{array}$ \\
\hline Controle (noradrenalina) & $5,2 \pm 0,03$ & - \\
Ropivacaína $5 \mu \mathrm{g} \cdot \mathrm{mL}^{-1}$ & $5,4 \pm 0,05$ & $+47,1 \pm 8,4^{*}$ \\
Ropivacaína $25 \mu \mathrm{g} \cdot \mathrm{mL}^{-1}$ & $5,3 \pm 0,07$ & $+25,1 \pm 8,1^{*}$ \\
Ropivacaína $50 \mu \mathrm{g} \cdot \mathrm{mL}^{-1}$ & $5,0 \pm 0,1$ & $-30,6 \pm 3,0^{*}$ \\
Ropivacaína $100 \mu \mathrm{g} \cdot \mathrm{mL}^{-1}$ & $5,3 \pm 0,07$ & $-63,1 \pm 2,2^{*}$ \\
Cocaína 1 $\mu \mathrm{M}$ & $5,2 \pm 0,05$ & $+20,4 \pm 1,7^{*}$ \\
\hline
\end{tabular}

Os valores são média \pm S.E.M, $n=5$

${ }^{*} \mathrm{p}<0,05$ versus controle

$(+)$ e (-) significam aumento e diminuição de Emax, respectivamente

Por outro lado, a ropivacaína nas concentrações de 5 ou 25 $\mu \mathrm{g} \cdot \mathrm{mL}^{-1}$ potencializou o $\mathrm{E}_{\max }$ da noradrenalina, enquanto que nas concentrações de 50 ou $100 \mu \mathrm{g} \cdot \mathrm{mL}^{-1}$ causou inibição do $\mathrm{E}_{\max }$ induzido por este agonista. A cocaína $1 \mu \mathrm{M}$ também potencializou o $\mathrm{E}_{\max }$ da noradrenalina sem alterar o valor de $\mathrm{pD}_{2}$ (Figura 1).

Em ductos de ratos tratados com reserpina, a ropivacaína (5e $25 \mu \mathrm{g} \cdot \mathrm{mL}^{-1}$ ) potencializou o $\mathrm{E}_{\max }$ da noradrenalina (concentração submáxima, $3 \mu \mathrm{M}$ ) em $116 \%$ e $75 \%$, respectivamente, enquanto que a cocaína potencializou em $57,6 \%$. Nas concentrações de 50 e $100 \mu \mathrm{g} \cdot \mathrm{mL}^{-1}$ a ropivacaína não alterou o $E_{\max }$ induzido pela noradrenalina (Figura 2). A adição de tiramina $(30 \mu \mathrm{M})$ após a noradrenalina não alterou o tônus basal dos ductos isolados de ratos tratados com reserpina (Figura 2).

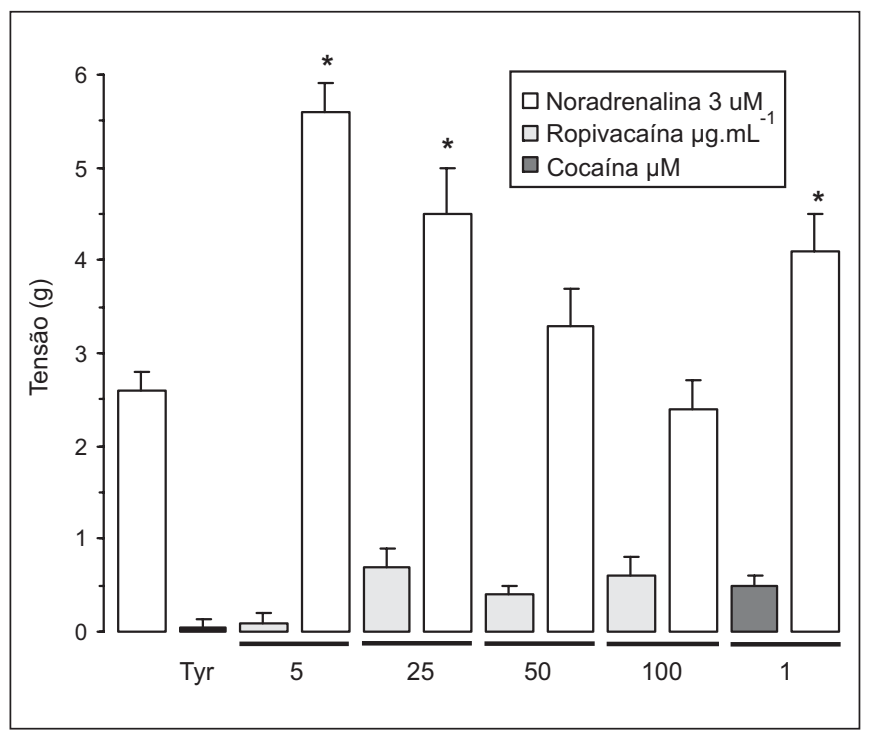

Figura 2 - Efeito da Ropivacaína ou Cocaína na Contração Induzida pela Noradrenalina em Ductos Deferentes Isolados de Ratos Reserpinizados

As colunas e barras verticais representam, respectivamente, as médias \pm S.E.M, $\mathrm{n}=5$

${ }^{*} p<0,05$ versus noradrenalina na ausência de ropivacaína ou cocaína (controle). Tyr (tiramina)

\section{DISCUSSÃO}

Os resultados obtidos neste estudo mostram que a ropivacaína modula, de maneira bifásica, a reatividade do ducto deferente de rato à noradrenalina. A ropivacaína, nas concentrações de 5 e $25 \mu \mathrm{g} \cdot \mathrm{mL}^{-1}$, promoveu potencialização, enquanto nas de 50 e $100 \mu \mathrm{g} \cdot \mathrm{mL}^{-1}$ causou redução do efeito máximo das curvas de contração induzidas por noradrenalina em ducto deferente de rato.

Atualmente está bem estabelecido que a contração induzida por noradrenalina em ducto deferente de rato, envolve ativação de $\alpha_{1}$-adrenoceptores ligados a proteína $\mathrm{G}$ ativadora de fosfolipase C, a qual promove hidrólise de fosfatidilinositóis, originando os segundos mensageiros intracelulares trifosfato de inositol $\left(\mathrm{IP}_{3}\right)$ e diacilglicerol (DAG), os quais mobilizam cálcio intracelular para contração muscular ${ }^{16,17}$.

Semelhante ao efeito da ropivacaína em baixas doses, a cocaína $1 \mu \mathrm{M}$ também potencializou o efeito máximo das curvas de contração induzida por noradrenalina, o que está de acordo com a literatura, mostrando que a cocaína inibe o sistema de recaptação neuronal de noradrenalina no tecido periférico ${ }^{12,18,19}$.

Portanto, os resultados sugerem que a ropivacaína, em baixas concentrações, potencializou a reatividade do ducto deferente à noradrenalina, caracterizado por aumento do $E_{\max }$ deste agonista, provavelmente devido à inibição do sistema de recaptação neuronal de aminas, o qual resultaria em maior disponibilidade extracelular desta catecolamina, conseqüentemente ativação, em maior tempo e quantidade de $\alpha_{1}$-adrenoceptores. Por outro lado, a ropivacaína em altas concentrações induziu uma diminuição da reatividade do ducto à noradrenalina, caracterizada por redução do $E_{\max }$ deste agonista em preparações não reserpinizadas, provavelmente devido a sua ação anestésica local direta, deprimindo o músculo liso, e/ou estabilizadora de membrana decorrente do bloqueio dos canais de cálcio, uma vez que a contração tônica do músculo liso é dependente de cálcio externo ${ }^{17,20}$.

Em relação à estrutura química, apesar de não haver correlação entre as estruturas planares da ropivacaína e da cocaína, além disso, a cocaína ser um éster e a ropivacaína uma amida, ambas mostraram no modelo experimental a mesma resposta.

Os resultados obtidos no modelo experimental usado permitem concluir que da mesma forma que a cocaína, a ropivacaína também bloqueia a recaptação neuronal de norepinefrina pelos terminais nervosos simpáticos.

\section{AGRADECIMENTOS}

A Universidade Federal do Maranhão, Conselho Nacional de Desenvolvimento Científico e Tecnológico - CNPq e Astrazeneca pelo fornecimento da ropivacaína.

Revista Brasileira de Anestesiologia Vol. 55, N 5 , Setembro - Outubro, 2005 


\section{Effect of Ropivacaine on Neuronal Norepinephrine Reuptake in Smooth Muscle}

Carlos Alberto de Souza Martins, TSA, M.D.; Pedro Wanderley de Aragão, M.D.; Sonia Maria de Farias Freire, M.D.; Mahiba Mattar Rahbani de Souza Martins, M.D.; Marilene Oliveira da Rocha Borges, M.D.; Antonio Carlos Romão Borges, M.D.

\section{INTRODUCTION}

Ropivacaine (1-propyl-2'-6 pipecoloxylidide hydrochloride) is a long-lasting local anesthetic chemically homologous to mepivacaine and bupivacaine. Pre-clinical trials have shown that ropivacaine is less toxic for central nervous and cardiovascular systems as compared to bupivacaine ${ }^{1}$, which is the most widely used drug for anesthetic blocks as a function of its prolonged action.

In clinical trials, healthy volunteers submitted to intravenous ropivacaine have shown less intense reactions on these two systems ${ }^{2,3}$, which is extraordinarily interesting due to the always present possibility of high concentrations reaching the blood as a consequence of inadvertent intravascular injection. Although ropivacaine exhibits sensory nerve blocking properties similar to those observed with bupivacaine ${ }^{4}$, the same is not true with regard to motor block because there is a well shown sensory-motor separation with ropivacaine ${ }^{5,6}$. Another property of ropivacaine is its clinically significant vasoconstrictor action ${ }^{7}$, observed during infiltrative anesthesia, which makes it attractive for field blockade ${ }^{8}$.

The association of epinephrine to ropivacaine is not a major factor for decreasing absorption from injection sites or for its prolonged effect ${ }^{9}$, as occurs to other local anesthetics, except cocaine. Pre-clinical trials have shown that high ropivacaine concentrations promote spinal cord vasoconstriction in rats, which is reversible within 20 minutes $^{10}$. This vasoconstrictor action of ropivacaine and cocaine is not shared by other local anesthetics, such as bupivacaine, in spite of their chemical similarities. Conversely, bupivacaine induces vascular relaxation after contraction by chemical or electrical stimulation. This muscle relaxing effect is due to depression of adrenergic neurotransmission as well as to inhibition of vascular smooth muscle activity ${ }^{11}$.

Considering that local anesthetic effect is a consequence of action on sodium channels and that these have little influence in vascular smooth muscle contraction, it is feasible to assume that ropivacaine-induced vasoconstriction is promoted by interference with sympathetic autonomous nervous system, similarly to cocaine, which is an alkaloid obtained from eritroxylon coca and is characterized by local anesthetic action and ability to block neuronal norepinephrine reuptake ${ }^{12}$. This study aimed at characterizing mechanisms of the constrictor action of ropivacaine on smooth muscles.

\section{METHODS}

This study was performed with Wistar rats of the species Rattus norvegicus and variety albino (200-220 g, 60 days of age), supplied by the Lab Animals Facility, Universidade Federal, Maranhão. Animals were adapted to the pharmacology laboratory for 15 days before starting the experiment and were kept under controlled conditions. Animals received free water and food during the study period. All procedures and protocols of this trial were submitted to and approved by the Research Ethics Committee, Hospital Universitário Presidente Dutra, UFMA.

Rats were anesthetized with sulfuric ether and sacrificed by cervical vessels section. Vasa deferentia were dissected and their lumen washed with vesicle nutritional fluid (VNF) with the following composition in $\mathrm{mM}$ : $\mathrm{NaCl}=138 ; \mathrm{KCl}=5.7$; $\mathrm{NaH}_{2} \mathrm{PO}_{4}=0.4 ; \mathrm{NaHCO}_{3}=15 ;$ Glucose $=5.5 ; \mathrm{CaCl}_{2}=1.8$. Preparations were assembled in isolated organ contraction chamber with aerated VNF at $30^{\circ} \mathrm{C}$ and adapted to a recording system preloaded with $1 \mathrm{~g}$ tension. After system stabilization (30 $\mathrm{min}$ ), norepinephrine concentration-effect curves were plotted in the absence or presence of ropivacaine or cocaine. Concentration-effect curves were also plotted from rats treated with intraperitoneal reserpine $\left(10 \mathrm{mg}^{\mathrm{kg}}{ }^{-1}\right)$ and sacrificed 24 hours later to evaluate vas reactivity to tyramine and norepinephrine in the absence or presence of ropivacaine.

Percentage of contraction as a function of maximum norepinephrine induced contraction in control curves was related to negative logarithms of agonist molar concentrations. $\mathrm{EC}_{50}$ (effective $50 \%$ concentration), $\mathrm{pD}_{2}\left(\mathrm{EC}_{50}\right.$ negative logarithm) and $E_{\max }$ (maximum effect) produced by norepinephrine in the absence or presence of ropivacaine or cocaine were determined from obtained concentration-effect curves. Values of $\mathrm{pD}_{2}$ and $\mathrm{E}_{\max }$ were expressed as mean \pm standard error (S.E.M.) and differences between norepinephrine effects in the absence or presence of ropivacaine or cocaine were determined by Student's $t$ test for a significance level of $5 \%(p<0.05)^{15}$.

\section{RESULTS}

Successive norepinephrine addition has produced concentration-dependent contractions, reaching $E_{\max }$ with $0.1 \mathrm{mM}$ and generating $\mathrm{pD}_{2}=5.2 \pm 0.03$. Incubation in ropivacaine $(5$, 25 or $100 \mu \mathrm{g} \cdot \mathrm{mL}^{-1}$ ) caused concentration-independent low amplitude contraction. In addition, it did not significantly change $\alpha_{1}$-adrenoreceptor system sensitivity $\left(\mathrm{pD}_{2}\right)$ to norepinephrine in vas deferens of rats (Figure 1 and Table I). On the other hand, 5 or $25 \mu \mathrm{g} \cdot \mathrm{mL}^{-1}$ ropivacaine concentrations potentiated norepinephrine $E_{\max }$, while 50 or 100 $\mu \mathrm{g} \cdot \mathrm{mL}^{-1}$ inhibited $E_{\max }$ induced by this agonist. Cocaine (1 $\mu \mathrm{M})$ also potentiated norepinephrine $E_{\max }$ without changing $\mathrm{pD}_{2}$ value (Figure 1). 


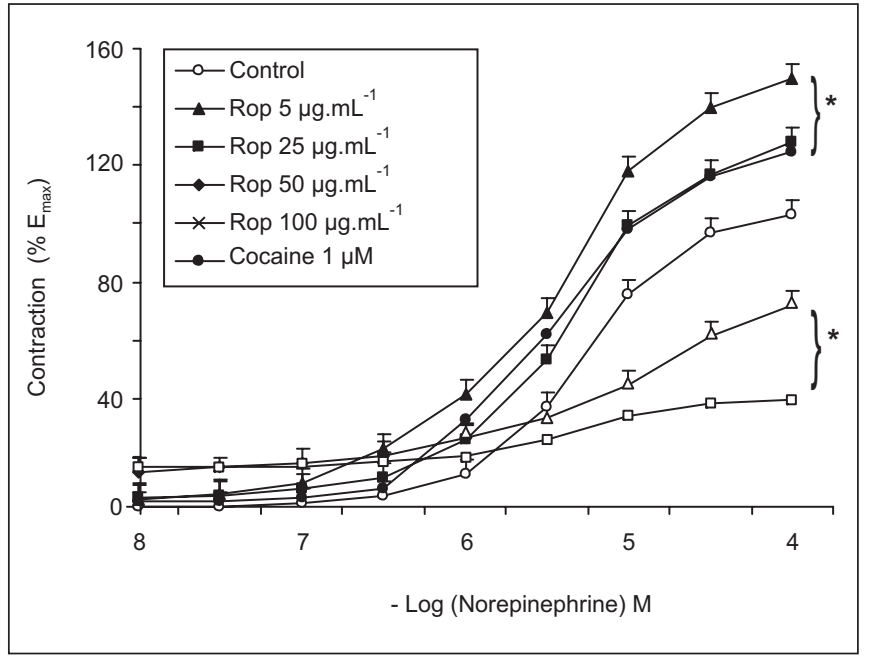

Figure 1 - Effect of Ropivacaine or Cocaine in Norepinephrine-induced Contraction (control) in Isolated Vas Deferens of Rats not Treated with Reserpine

Symbols and vertical bars represent, respectively, mean \pm S.E.M, $n=5$

${ }^{*} p<0.05$ versus norepinephrine in the absence of ropivacaine (control)

Table I - $\mathrm{pD}_{2}$ and $\mathrm{E}_{\max }$ Variation Obtained from Norepinephrine Concentration-Response Curves in the Absence or Presence of Ropivacaine or Cocaine

\begin{tabular}{lcc}
\hline Groups & $\mathrm{pD}_{2}$ & Emax Variation (\%) \\
\hline Control (norepinephrine) & $5.2 \pm 0.03$ & - \\
Ropivacaine $5 \mu \mathrm{g} \cdot \mathrm{mL}^{-1}$ & $5.4 \pm 0.05$ & $+47.1 \pm 8.4^{*}$ \\
Ropivacaine $25 \mu \mathrm{g} \cdot \mathrm{mL}^{-1}$ & $5.3 \pm 0.07$ & $+25.1 \pm 8.1^{*}$ \\
Ropivacaine $50 \mu \mathrm{g} \cdot \mathrm{mL}^{-1}$ & $5.0 \pm 0.1$ & $-30.6 \pm 3.0^{*}$ \\
Ropivacaine $100 \mu \mathrm{g} \cdot \mathrm{mL}^{-1}$ & $5.3 \pm 0.07$ & $-63.1 \pm 2.2^{*}$ \\
Cocaine $1 \mu \mathrm{M}$ & $5.2 \pm 0.05$ & $+20.4 \pm 1.7^{*}$ \\
\hline
\end{tabular}

Values in Means \pm S.E.M., $n=5$

${ }^{*} p<0.05$ versus control

$(+)$ and (-) mean $E_{\max }$ increase and decrease, respectively

In vasa of rats treated with reserpine, 5 and $25 \mu \mathrm{g} \cdot \mathrm{mL}^{-1}$ ropivacaine potentiated norepinephrine $\mathrm{E}_{\max }$ (submaximum concentration, $3 \mu \mathrm{M}$ ) in $116 \%$ and $75 \%$, respectively, while cocaine potentiated it in $57.6 \%$. In concentrations of 50 and $100 \mu \mathrm{g} \cdot \mathrm{mL}^{-1}$, ropivacaine did not change norepinephrine-induced $E_{\max }$ (Figure 2). The addition of tyramine $(30 \mu \mathrm{M})$ after norepinephrine did not change basal tone of isolated vasa of rats treated with reserpine (Figure 2).

\section{DISCUSSION}

Our results have shown that ropivacaine modulates rat vas deferens reactivity to norepinephrine in a two-phase manner. Ropivacaine in 5 and $25 \mu \mathrm{g} \cdot \mathrm{mL}^{-1}$ concentrations promoted potentiation, while in 50 to $100 \mathrm{~g} \cdot \mathrm{mL}^{-1}$ concentrations decreased maximum effect of concentration curves induced by norepinephrine in vas deferens of rats.

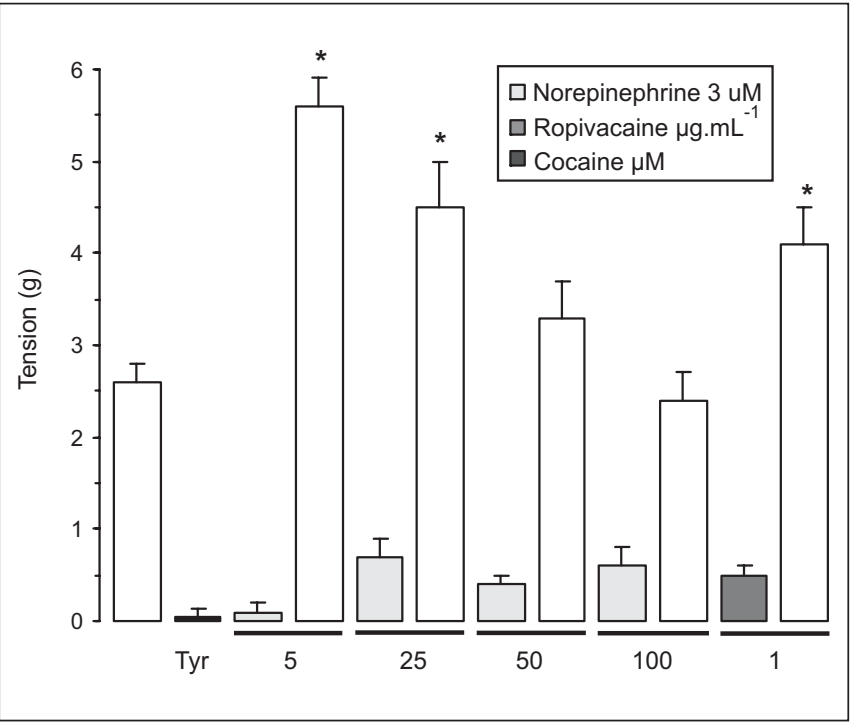

Figure 2 - Effect of Ropivacaine or Cocaine on Norepinephrine-Induced Contraction of Isolated Vas Deferens of Rats not Treated with Reserpine

Columns and vertical bars represent, respectively, mean \pm S.E.M, $n=5$

${ }^{*} p<0.05$ versus norepinephrine in the absence of ropivacaine (control). Tyr (tyramine)

It is currently well-established that norepinephrine-induced contraction in vas deferens of rats involves the activation of $\alpha_{1}$-adrenoreceptors bound to phospholipase $C$ activating $G$ protein, which promotes hydrolysis of phosphatidinositol originating the second-messengers inositol triphosphate $\left(\mathrm{IP}_{3}\right)$ and diacylglycerol (DAG), which mobilize intracellular calcium for muscle contraction ${ }^{16,17}$

Similarly to low bupivacaine doses, $1 \mu \mathrm{M}$ cocaine has also potentiated maximum effect of norepinephrine-induced contraction curves, which agrees with the literature and shows that cocaine inhibits neuronal norepinephrine reuptake system in peripheral tissue ${ }^{12,18,19}$.

Our results suggest that low ropivacaine concentrations have potentiated vas deferens reactivity to norepinephrine, characterized by increased $\mathrm{E}_{\max }$ of this agonist, probably due to neuronal amine reuptake system inhibition, which would result in greater extracellular availability of this catecholamine and, as a consequence, in activation of $\alpha_{1}$-adrenoreceptos for a longer time. On the other hand, high ropivacaine concentrations have induced decreased vas reactivity to norepinephrine, characterized by decreased $\mathrm{E}_{\max }$ of this agonist in preparations without reserpine, probably due to its direct effect depressing smooth muscle and/or membrane stabilizing effect as a consequence of calcium channels block, since smooth muscle tonic contraction is dependent on external calcium ${ }^{17,20}$.

In terms of chemical structure, although there is no correlation between ropivacaine and cocaine planar structures and in spite the fact that cocaine is an ester and ropivacaine an amide, both have shown the same response in our experimental model. 
Results obtained in our experimental model suggest that, similarly to cocaine, ropivacaine also blocks neuronal norepinephrine reuptake by sympathetic nervous terminals.

\section{ACKNOLEDGMENTS}

We acknowledge Universidade Federal do Maranhão, Conselho Nacional de Desenvolvimento Científico e Tecnológico - CNPq and Astrazeneca for supplying ropivacaine.

\section{REFERÊNCIAS - REFERENCES}

01. Feldman HS - Toxicity of Local Anesthetic Agents, em: Rice AS, Fish KJ - Anesthetic Toxicity. New York, Raven Press, 1994;7:107-133.

02. Pitkanen M, Feldman HS, Arthur GR et al - Chronotropic and inotropic effects of ropivacaine, bupivacaine, and lidocaine in the spontaneously beating and electrically paced isolated, perfused rabbit heart. Reg Anesth, 1992;17:183-192.

03. Scott DB, Lee A, Fagan D et al - Acute toxicity of ropivacaine compared with that of bupivacaine. Anesth Analg, 1989;69:563-569.

04. Brockway MS, Bannister J, McClure JH et al - Comparison of extradural ropivacaine and bupivacaine. $\mathrm{Br} \mathrm{J}$ Anaesth, 1991;66:31-37

05. Bader AM, Datta S, Flanagan $\mathrm{H}$ et al - Comparison of bupivacaine and ropivacaine-induced conduction blockade in the isolated rabbit vagus nerve. Anesth Analg, 1989;68:724-727.

06. Morrison LM, Emanuelsson BM, McClure JH et al - Efficacy and kinetics of extradural ropivacaine: comparison with bupivacaine. Br J Anaesth, 1994;72:164-169.

07. Lofstrom JB - The effect of local anesthetics on the peripheral vasculature. Reg Anesth, 1992;17:1-11.

08. Guinard JP, Carpenter RL, Morell RC - Effect of local anesthetic concentration on capillary blood flow in human skin. Reg Anesth, 1992;17:317-321.

09. Hickey R, Blanchard J, Hoffman J et al - Plasma concentrations of ropivacaine given with or without epinephrine for brachial plexus block. Can J Anaesth, 1990;37:878-882.

10. Kristensen JD, Karlsten R, Gordh T - Spinal cord blood flow after intrathecal injection of ropivacaine: a screening for neurotoxic effects. Anesth Analg, 1996;82:636-640.

11. Muldoon SM, Verbeuren TJ, Vanhoutte PM - Effects of amide-linked local anesthetics on adrenergic neuroeffector junction in cutaneous veins of dog. J Pharmacol Exp Ther, 1976:196:723-736.

12. Trendelenburg $U$ - Mechanisms of supersensivity and subsensivity to sympathomimetic amines. Pharmacol Rev, 1966;18:629-640.

13. Freire SM, Torres LM, Souccar $C$ et al - Sympathomimetic effects of Scoparia dulcis L. and catecholamines isolated from plant extracts. J Pharm Pharmacol, 1996;48:624-628.
14. Van Rossum JM - Cumulative dose-response curves. II Technique for the making of dose-response curves in isolated organs and the evaluation of drug parameters. Arch Int Pharmacodyn, Ther, 1963;143:299-330.

15. Sokal RR, Rohlf FJ - Biometry: The Principle and Practice of Statistics. New York, WH Freeman and Company, 1984.

16. Amobi NI, Sugden D, Smith IC - Pharmacomechanical coupling in rat vas deferens: effects of agents that modulate intracellular release of calcium and protein kinase $\mathrm{C}$ activation. Life Sci, 1999;65:145-156.

17. Han C, Abel PW, Minneman KP - Alpha 1-adrenoceptor subtypes linked to different mechanisms for increasing intracellular Ca2+ in smooth muscle. Nature, 1987;329:333-335.

18. Ramamoorthy S, Prasad PD, Kulantaivel P et al - Expression of a cocaine-sensitive norepinephrine transporter in the human placental syncytiotrophoblast. Biochemistry, 1993;32: 1346-1353.

19. Kasuya $Y$, Goto K - The mechanism of supersensitivity to norepinephrine induced by cocaine in rat isolated vas deferens. Eur J Pharmacol. 1968;4:355-362.

20. Shimuta SI, Borges AC, Prioste RN et al - Different pathways for $\mathrm{Ca} 2+$ mobilization by angiotensin II and carbachol in the circular muscle of the guinea-pig ileum. Eur J Pharmacol, 1999;367: 59-66.

\section{RESUMEN}

Martins CAS, Aragão PW, Freire SMF, Martins MMRS, Borges MOR, Borges ACR - Efecto de la Ropivacaína en la Recaptación Neuronal de Noradrenalina en un Músculo Liso

JUSTIFICATIVA Y OBJETIVOS: Además de la acción anestésica local, la ropivacaína presenta un efecto vasoconstrictor, clínicamente significativo y puede ser observado cuando de la anestesia infiltrativa, con esto lo hace un anestésico importante en el bloqueo del campo. Este trabajo tuvo por objetivo caracterizar el mecanismo de acción constrictor de la ropivacaína en músculo liso.

MÉTODO: En preparaciones separadas del conducto deferente de ratones fueron construidas curvas concentración-efecto de noradrenalina en la ausencia o en la presencia de la ropivacaína. En otra serie de experimentos los ratones fueron tratados con reserpina $10 \mathrm{mg}^{\mathrm{kg}} \mathrm{kg}^{-1}$, por la via intraperitoneal) para evaluar la reactividad de los conductos deferentes a la tiramina o noradrenalina, en la ausencia o presencia de la ropivacaína.

RESULTADOS: La ropivacaína en las concentraciones de 5 ó $10 \mu \mathrm{g} \cdot \mathrm{mL}^{-1}$ potenció el efecto máximo (Emax) de la noradrenalina en un $47 \%$ y $35 \%$, respectivamente, mientras que en las concentraciones de 50 ó $100 \mu \mathrm{g} \cdot \mathrm{mL}^{-1}$ inhibió el efecto máximo producido por este agonista. En conductos deferentes separados de ratones reserpinizados, la ropivacaína (10 ó $20 \mu \mathrm{g} \cdot \mathrm{mL}^{-1}$ ) potenció (150\% y 25\%, respectivamente) las contracciones inducidas por la noradrenalina, mientras que las concentraciones de 50 ó 100 $\mu \mathrm{g} \cdot \mathrm{mL}^{-1}$ no alteraron las respuestas a la noradrenalina.

CONCLUSIONES: Los resultados logrados permiten concluir que la ropivacaína bloquea la recaptación neuronal de noradrenalina por los terminales nerviosos simpáticos. 